\title{
Cooperative Learning Tipe Numbered Heads Together sebagai Alternatif Peningkatan Kualitas Pembelajaran pada Mata Kuliah Telaah Kurikulum Hasil Belajar Fisika SMA
}

\author{
Dian Artha Kusumaningtyas \\ Program Studi Pendidikan Fisika, Universitas Ahmad Dahlan, \\ Kampus III, J1. Prof. Dr. Soepomo, SH, Yogyakarta 55164 Indonesia \\ Surat-e: dian_uad@yahoo.com
}

Hal yang harus diperhatikan oleh pendidik dalam mengajarkan suatu pokok bahasan adalah pemilihan model pembelajaran yang sesuai dengan materi yang diajarkan. cooperative learning tipe numbered heads together (NHT). merupakan suatu metode belajar yang cukup efektif untuk meningkatkan partisipasi mahasiswa dikelas. Penelitian ini bertujuan Mengetahui perubahan kualitas proses belajar pada peserta didik yang diajar pendidik menggunakan cooperative learning tipe numbered heads together (NHT).

Subjek Penelitian ini adalah mahasiswa semester IV program studi P.Fisika. Rancangan penelitian ini menggunakan alur penelitian tindakan kelas menggunakan model Kemmis dan Mc. Taggart, yang diawali kegiatan perencanaan, pelaksanaan, observasi dan refleksi.

Hasil dari penelitian ini menunjukkan model pembelajaran kooperatif tipe Numbered Heads Together (NHT) dapat meningkatkan aktivitas belajar mahasiswa mata kuliah telaah kurikulum Fisika SMA. Hal ini tergambar dari rata-rata aktivitas siklus I mencapai 2,2 dan meningkat sebesar 3,3 pada siklus IV. Selain itu tampak prosentase keterlaksanaan dari siklus I mencapai rata-rata sebesar 2,78, dan siklus 4 mencapai rata-rata sebesar 3,57 atau meningkat sebesar 0.79 dari siklus I.

Kata kunci: cooperatif learning tipe NHT, kualitas pembelajaran

\section{Pendahuluan}

Dalam proses pembelajaran, salah satu hal yang harus diperhatikan oleh pendidik dalam mengajarkan suatu pokok bahasan adalah pemilihan model pembelajaran yang sesuai dengan materi yang diajarkan, karena melihat kondisi peserta didik yang mempunyai karakteristik yang berbeda antara satu dengan yang lainnya dalam menerima materi pelajaran yang disajikan pendidik di kelas, ada peserta didik yang mempunyai daya serap cepat dan ada pula peserta didik yang mempunyai daya serap yang lama (Wijaya, 2008).

Menyikapi kenyataan ini, peneliti menilai perlu digunakannya cooperative learning tipe numbered heads together (NHT). Menurut Wijaya (2008) menjelaskan NHT merupakan suatu metode belajar dimana setiap peserta didik diberi nomor kemudian dibuat suatu kelompok kemudian secara acak guru memanggil nomor dari peserta didik.

Dewasa ini Penelitian Tindakan Kelas (PTK) semakin menjadi perhatian untuk dilakukan oleh para profesional sebagai upaya pemecahan masalah dan peningkatan mutu diberbagai bidang. PTK sangat bermanfaat bagi pendidik untuk meningkatkan mutu proses dan hasil pembelajaran di kelas. Berdasarkan uraian di atas peneliti merasakan pentingnya menciptakan suasana pembelajaran yang menarik dan menyenangkan agar peserta didik berperan serta dalam aktivitas pembelajaran yang berlangsung. Oleh karena itulah, pada penelitian ini peneliti menggunakan model cooperative learning tipe numbered heads together (NHT) untuk meningkatkan kualitas dan aktivitas pembelajaran pada mata kuliah Telaah Kurikulum Fisika SMA I

Penelitian ini bertujuan Mengetahui perubahan kualitas proses belajar pada peserta didik yang diajar pendidik 
menggunakan cooperative learning tipe numbered heads together (NHT).

\section{Kajian Pustaka}

\section{Cooperative learning tipe numbered heads together (NHT)}

Pembelajaran kooperatif (cooperative learning) merupakan strategi pembelajaran yang mengutamakan adanya kerjasama antar peserta didik dalam kelompok untuk mencapai tujuan pembelajaran. (Latief, 2009: I3).

Lie (2008: 59) dalam bukunya yang berjudul coperative learning mengungkapkan teknik belajar NHT dikembangkan oleh Spencer Kagan tahun 1992. Teknik ini merupakan salah satu tipe dalam cooperative learning yang memberikan kesempatan kepada peserta didik untuk saling membagikan ide-ide dan mempertimbangkan jawaban yang paling tepat. Selain itu, teknik ini juga mendorong peserta didik untuk meningkatkan semangat kerjasama mereka. Teknik ini bisa digunakan dalam semua mata pelajaran dan untuk semua tingkatan anak didik.

\section{Belajar dan Pembelajaran}

Dalam (Hamalik, 2008: 36), belajar adalah modifikasi atau memperteguh kelakuan melalui pengalaman. Menurut pengertian ini, belajar merupakan suatu proses, suatu kegiatan dan bukan suatu hasil atau tujuan. Belajar bukan hanya mengingat, akan tetapi lebih luas daripada itu, yakni mengalami. Hasil belajar bukan suatu penguasaan hasil latihan, melainkan perubahan kelakuan.

Pembelajaran adalah suatu kombinasi yang tersusun meliputi unsur-unsur manusiawi, material, fasilitas, perlengkapan, dan prosedur yang saling mempengaruhi mencapai tujuan pembelajaran. Manusia terlibat dalam system pengajaran yang terdiri dari siswa, guru, dan tenaga lainnya, misalkan tenaga laboraturium. Material, meliputi buku-buku, papan tulis, dan kapur, slide dan film, audio dan video tape. Fasilitas dan perlengkapan, terdiri dari ruangan kelas, perlengkapan audio visual, juga computer. Prosedur, meliputi jadwal dan metode penyampaian informasi, praktik, belajar, ujian dan sebagainya.

Uno (2008:3) mengatakan bahwa istilah motivasi berasal dari kata motif yang berarti kekuatan yang terdapat dalam diri individu yang menyebabkan individu itu berbuat atau bertindak. Motivasi diterapkan dalam berbagai kegiatan dan tidak terkecuali belajar. Pentingnya motivasi dalam belajar karena keberadaannnya sangat berarti bagi perbuatan belajar. Motivasi pada dasanya dapat membantu dalam memahami dan menjelaskan perilaku individu.

\section{Penelitian tindakan kelas (PTK)}

Istilah PTK dalam bahasa Inggris adalah Classtoom Action Research (CAR). Dalam istilah tersebut terdiri dari tiga buah kata yang membentuk pengertian tersebut. Penelitian adalah kegiatan mencermati suatu objek dengan menggunakan metodologi tertentu untuk memperoleh data atau informasi, tindakan adalah suatu gerak kegiatan yang sengaja dilakukan dengan tujuan tertentu dan dalam penelitian ini berbentuk rangkaian siklus kegiatan, sedangkan kelas sekelompok peserta didik yang sedang belajar baik dalam kelas, laboratorium, lapangan, ataupun workshop (Aqib, 2008: I2).

Ada beberapa model PTK yang sampai saat ini sering digunakan di dalam dunia pendidikan, diantaranya adalah : (I) model Kurt Lewin yang terdiri dari perencanaan, aksi, observasi dan refleksi; (2) model Kemmis dan Mc Taggart yang terdiri dari perencanaan, tindakan, observasi dan refleksi; (3) model John Elliot, model ini tampak lebih rinci karena di dalam setiap siklus terdiri dari beberapa aksi; dan (4) model Dave Ebbutt (Aqib, 2008: 2I).

\section{Metode Penelitian}

\section{Perencanaan}

Pada tahap perencanaan (planning), kegiatan yang dilakukan adalah:

a. Peneliti membuat rencana pelaksanaan pembelajaran (RPP)

b. Peneliti menyiapkan bahan materi pembelajaran

c. Peneliti mensosialisasikan kepada mahasiswa mengenai teknis pelaksanaan model cooperative learning tipe numbered heads together (NHT)

\section{Tindakan}

Pada tahap pelaksanaan tindakan ini, kegiatan yang dilakukan adalah peneliti melaksanakan rencana pembelajaran yang telah direncanakan pada tahap sebelumnya yaitu dengan menggunakan model cooperative learning tipe numbered heads together (NHT) dan observer mengamati aktivitas mahasiswa dan dosen selama pembelajaran berlangsung. Adapun langkah-langkah model cooperative learning tipe numbered heads together (NHT)

Adapun alur penelitian tindakan kelas menggunakan model Kemmis dan Mc. Taggart sebagai berikut: 


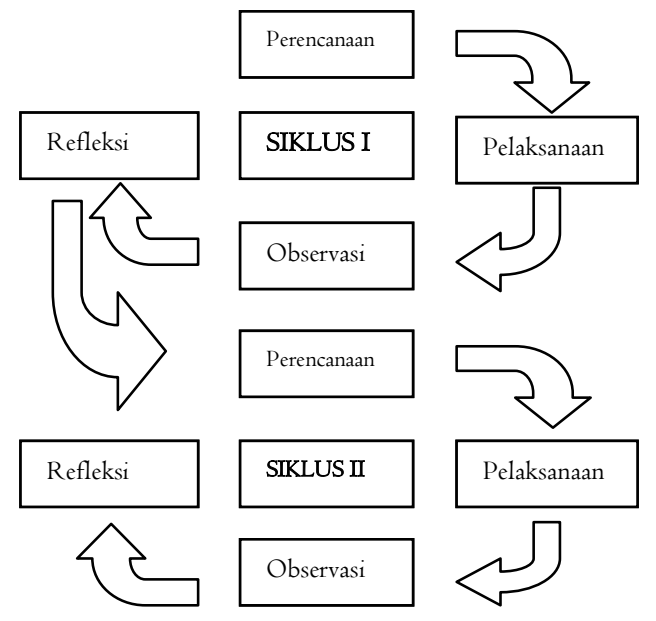

Gambar I. Skema Pelaksanaan Tindakan

Indikator Capaian penelitian ini adalah Aktivitas pembelajaran dan kualitas pembelajaran meningkat. Instrumen yang digunakan rencana pelaksanaan pembelajaran (RPP), lembar kerja kelompok, tes pemahaman materi, dan Lembar pengamatan untuk aktivitas dosen dan mahasiswa. Teknik Analisis Data dalam penelitian ini menggunakan metode deskriptif kualitatif. Data yang diperoleh dari hasil observasi sebelum tindakan dilakukan. Hasil observasi digunakan sebagai latar belakang masalah penelitian tindakan ini

\section{Hasil Penelitian dan Pembahasan}

\section{Data Hasil Penelitian}

Untuk mendapatkan gambaran rata-rata aktivitas Mahasiswa baik pada siklus I maupun siklus 4, dapat dilihat pada Gambar 2.

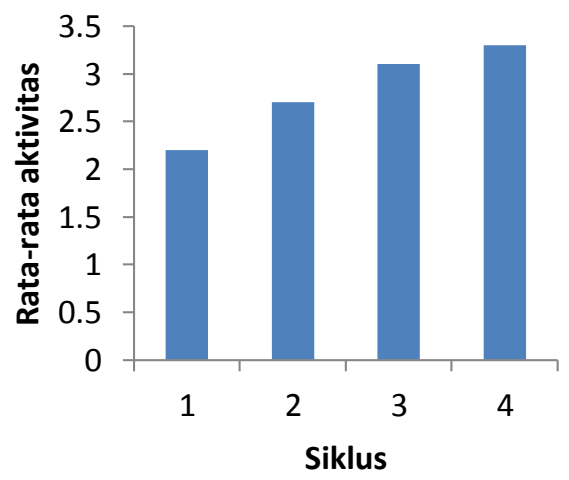

Gambar 2. Grafik Rata-Rata Aktivitas Mahasiswa Setiap Siklus
Berdasarkan gambar 2, menunjukkan rata-rata skor persatuan aktivitas Mahasiswa persiklus cenderung mengalami peningkatan ke arah yang lebih baik, dimana pada siklus I rata-rata skor persatuan aktivitas Mahasiswa umumnya berada pada kategori cukup, sedangkan pada siklus 4 rata-rata skor persatuan aktivitas Mahasiswa umumnya berada pada kategori baik, dengan rata-rata aktivitas Mahasiswa pada siklus I sebesar 2,2 meningkat sebesar I,I pada siklus 4 atau meningkat menjadi 3,3.

Untuk mendapatkan gambaran rata-rata aktivitas Dosen baik pada siklus I maupun siklus 4, dapat dilihat pada Gambar 3 berikut.

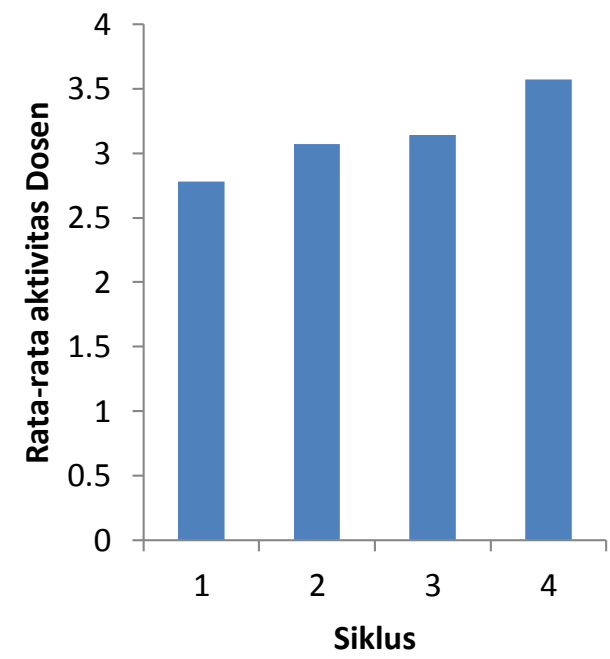

Gambar 3. Grafik Rata-Rata Aktivitas Dosen Setiap Siklus

Berdasarkan Gambar 3 di atas, menunjukkan adanya peningkatan aktivitas Dosen yang signifikan baik pada siklus I maupun siklus 4, dimana rata-rata aktivitas dosen pada siklus I sebesar 2,78 mengalami peningkatan sebesar 0,79 pada siklus 4 atau meningkat menjadi 3,57

\section{Analisis dan Pembahasan}

Berdasarkan permasalahan utama tentang bagaimana gambaran aktivitas belajar Mahasiswa dalam kegiatan belajar mengajar pada materi ajar telaah kurikulum Fisika SMA yang diajar dengan menggunakan model pembelajaran kooperatif tipe NHT (Numbered Heads Together), dapat dijelaskan berdasarkan hasil pengamatan pada siklus I sampai siklus 4 yang cenderung mengalami peningkatan ke arah yang lebih baik, dimana rata-rata aktivitas Mahasiswa dapat dilihat pada Tabel I. Dari tabel tersebut, rata-rata aktivitas Mahasiswa pada siklus I sampai siklus 4 
cenderung mengalami peningkatan. Peningkatan aktivitas Mahasiswa tersebut, menunjukkan adanya minat dan antusias Mahasiswa dalam mengikuti pembelajaran pada materi ajar persamaan linear satu variabel dengan penerapan model pembelajaran kooperatif tipe NHT (Numbered Heads Together).

Peningkatan rata-rata aktivitas Mahasiswa pada setiap siklus tersebut menandakan bahwa Mahasiswa mulai aktif dalam mengikuti pembelajaran. Hasil observasi yang dilakukan peneliti menunjukkan bahwa pelaksanaan pembelajaran dengan penerapan model pembelajaran kooperatif tipe NHT (Numbered Heads Together) dapat memberikan hasil yang lebih baik walaupun masih terdapat satuan aktivitas yang tidak mengalami peningkatan yang signifikan dan tergolong dalam kategori cukup seperti aktivitas Mahasiswa dalam mengajukan pertanyaan kepada Dosen saat mengalami kesulitan dalam menyelesaikan masalah dalam LKM, namun Mahasiswa sudah aktif membantu rekan-rekan sekelompoknya untuk menyelesaikan soal-soal yang diberikan.

Berdasarkan hasil analisis deskriptif terhadap aktivitas Mahasiswa pada setiap siklus menunjukkan bahwa penerapan model pembelajaran kooperatif tipe NHT mampu meningkatkan aktivitas belajar Mahasiswa sehingga tampak bahwa pembelajaran yang dilakukan dalam penelitian ini lebih terpusat pada Mahasiswa (student centre), dimana peran Dosen dalam pembelajaran hanya bersifat sebagai mediator.

\section{Kesimpulan}

Berdasarkan hasil analisis dari beberapa siklus dan pembahasan, maka dapat disimpulkan bahwa model pembelajaran kooperatif tipe Numbered Heads Together (NHT) dapat meningkatkan aktivitas belajar mahasiswa mata kuliah telaah kurikulum Fisika SMA. Hal ini tergambar dari rata-rata aktivitas siklus I mencapai 2,2 dan meningkat sebesar 3,3 pada siklus IV. Selain itu tampak prosentase keterlaksanaan dari siklus I mencapai rata-rata sebesar 2,78, dan siklus 4 mencapai rata-rata sebesar 3,57 atau meningkat sebesar 0.79 dari siklus I.

\section{KEPUSTAKAAN}

Aqib, Zainal. 2008. Penelitian Tindakan Kelas untuk Guru. Bandung: Yrama Widya.

Arikunto, Suharsimi, Suhardjono dan Supardi. 2008. Penelitian Tindakan Kelas. Jakarta: Bumi Aksara.

Arikunto, Suharsimi. 2006. Prosedur Penelitian Suatu Pendekatan Praktik. Jakarta: Rineka Cipta.
Cooperative Learning Tipe Numbered Heads Together Sebagai Alternatif Peningkatan Kualitas Pembelajaran Pada Mata Kuliah Telaah Kurikulum Hasil Belajar Fisika SMA

Arikunto, Suharsimi. 2007. Dasar-dasar Evaluasi Pendidikan (Edisi Revisi). Jakarta: Bumi Aksara.

Dimyati dan Mudjiono. 2002. Belajar dan Pembelajaran. Jakarta: Rineka Cipta.

Hamalik,Oemar.2008. Proses Belajar Mengajar.Jakarta:Bumi Aksara

Latief, Nurwahyuni. 2009. Model Pembelajaran Kooperatif Tipe NHT. $\quad$ http://pendidikanmatematika.blogspot.com/2009/03/contoh-skripsimodel-pembelajaran.html

Lie, Anita. 2008. Cooperative Learning Mempraktikkan Cooperative Learning di Ruang-ruang Kelas. Jakarta: Grasindo.

Purwanto, M Ngalim. 2004. Psikologi Pendidikan. Bandung: Penerbit PT Remaja Rosdakarya.

Sardiman. 2007. Interaksi dan Motivasi Belajar Mengajar. Jakarta: PT Raja Grafindo Persada.

Susilo, Muhammad Joko. 2006. Bekal Bagi Calon Guru Belajar dan Mengajar. Yogyakarta: Universitas Ahmad Dahlan.

Uno, Hamzah B. 2008. Teori Motivasi dan Pengukurannya Analisis di Bidang Pendidikan. Jakarta: Bumi Aksara 